\title{
Considerations On The Use Of Xenogenous Bone Blocks In Implantology: A Case Report
}

\author{
Consideraciones en el Uso de Injerto en Bloque Xenógeno en \\ Implantología: Reporte de Caso
}

\begin{abstract}
Patrick Barlatti Rocha ${ }^{*, * *}$; Cleydiane Teles da Silva ${ }^{*, * *}$; Simei Silva de Santana-Júnior ${ }^{*, * *}$; Virgílio de Miranda Camargo ${ }^{*, *}$; Claudio Ferreira Nóiaa,** \& Bruno Costa Martins de Sá*,**
\end{abstract}

ROCHA, P. B.; DA SILVA, C. T.; DE SANTANA-JÚNIOR, S. S.; CAMARGO, V. M.; NÓIA, C. F. \& DE SÁ, B. C. M. Considerations on the use of xenogenous bone blocks in implantology: A case report. Int. J. Med. Surg. Sci., 2(2):469-474, 2015.

SUMMARY: In implantology, an increase in the bone thickness of the alveolar ridge is often associated with the use of autogenous bone, which is considered to be the gold standard. The aim of the present study was to report the clinical case of a patient with abnormal bone thickness in the alveolar ridge, causing severe esthetical damage, and the use of xenogeneic block bone grafts. A female, 43-year old patient exhibited a considerable bone defect in the region of teeth 11 (absent), although there was sufficient native bone available for the implantation. The patients treatment involved positioning the implant and performing a block bone graft using bone of bovine origin. The post-operative period passed without complications. The post-operative clinical examination confirmed the correction of the pre-existing esthetic defect and the health of the soft tissues involved. The tomographic examination 180 days post-surgery also confirmed an excellent increase in thickness. The bovine block bone graft used in the present case was shown to be viable in terms of correcting esthetic defects when there is sufficient native bone available for the implantation.

KEY WORDS: Alveolar ridge augmentation; Bone transplantation; Dental implants.

\section{INTRODUCTION}

Bone resorption occurs naturally after the loss of a tooth and hinders the adequate installation of dental implants. Consequently, the need to correct bone defects, with a view to posterior rehabilitation with implants, has become routine for professionals operating in this area (Rothamel et al., 2009; Li et al., 2013).

Autogenous bone is generally selected for this type of treatment as it is cited as the gold standard in the scientific literature, particularly in cases involving critical defects of the alveolar ridge. The popularity of autogenous material is due to the large number of studies citing its successful use in the literature, which reassures health professionals when selecting material, as well as the fact that it is the only material that exhibits all of the ideal properties for bone neoformation (osteoconduction, osteoinduction and osteogenesis) (Nóia et al., 2012a, 2012b; Xuan et al., 2014).

However, one disadvantage of autogenous material is that it is obtained directly from the patient, which leads to greater levels of postoperative morbidity and a greater risk of complications (Nóia et al., 2012a, 2012b; Xuan et $a /$.$) . Thus, tireless research is currently$ underway to find a material that could replace autogenous material, while exhibiting similar biological properties and the ability to stimulate bone neoformation.

* Dentistry Department, University of Araras (UNIARARAS/SP), Araras, Brazil.

** Dentistry Department, College Ciodonto, Rondônia, Brazil. 
In practical terms, there have been recent improvements in biomaterials, particularly those of xenogenous origin in particulate form. These were mostly obtained from cortical bone areas in the past, but are now being taken from medullary (or cortico-medullary) areas by several companies.

This evolution was not matched for autogenous material, although it did enable their safe use in cases of more predictable ridge defects, such as maxillary sinus, dental alveoli and exposed implant screws (Kühl et al., 2012, 2013).

Xenogenous material is currently available on the market in the form of blocks, although it is not fully trusted or understood by most professionals, since there has not yet been a single protocol indicating the use of this material in the scientific literature.

Therefore, the aim of the present study was to report a clinical case that used a xenogenous block for an immediate implant in the anterior maxillary region.

\section{CASE REPORT}

A 43-year old female patient with leucoderma requested dental implants due to the loss of a dental element, which had damaged her facial esthetics and function.

The clinical examination confirmed the absence of dental element 11 , with the continuous use of a fixed adhesive prosthesis in the area. After removing the prosthesis, vestibular and occlusal views confirmed the existence of a considerable depression in the area, as well as the presence of keratinized gingiva (Figs. 1 and 2). A tomographic examination revealed a bone thickness of 3.58 $\mathrm{mm}$ and a bone height of $16.91 \mathrm{~mm}$ in the area (Fig. 3).

The proposed treatment plan involved the positioning of an implant with bone expansion ability, associated with a bovine block bone graft to correct the esthetic defect during the same surgical procedure.

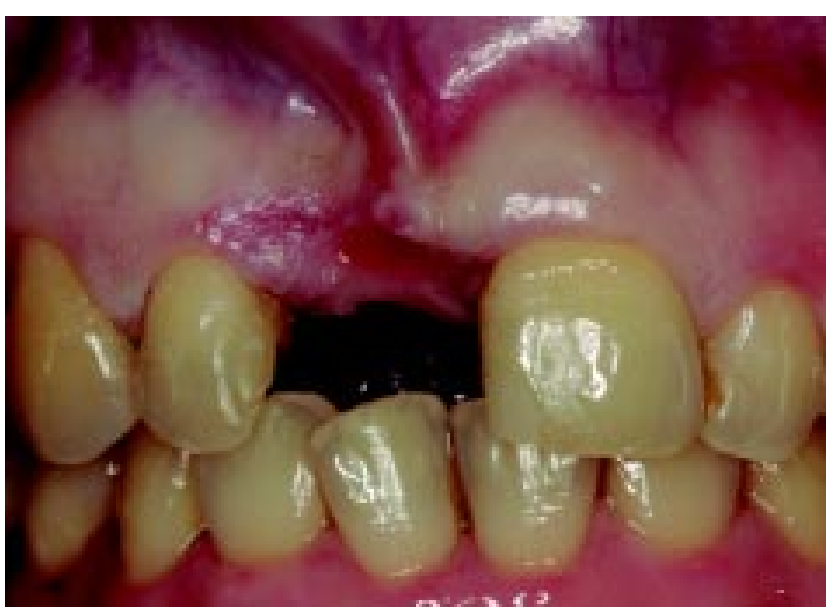

Fig. 1. Vestibular view of the region around element 11 (absent). Note the considerable depression that exists.

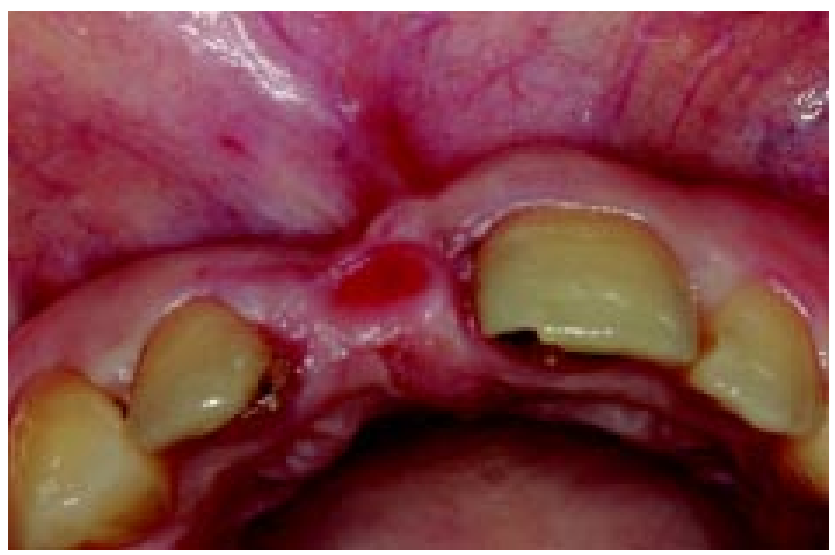

Fig. 2. Occlusal view of the region around element 11 (absent). Note the depression that exists, the presence of attached gingiva and the appearance of the tissue in the area.

The surgical procedure began with the anesthetic blocking of the anterior, superior and nasopalatine alveolar nerves. This was done using mepivacaine solution ( $2 \%$ ) with a vasoconstrictor of $1: 100,000$ (Dfl, Rio de Janeiro-Brazil). Subsequently, an incision was made on the edge of the ridge, together with two relaxing incisions on the distal surfaces of the adjacent teeth. After careful mucoperiosteal detachment, it was possible to confirm the presence of a bone depression and an adequate quantity of soft tissue for the installation of the implant (Fig. 4). Milling was then performed as recommended by the manufacturer.

During the installation of the cone morse implant (Titamax $3.5 \times 11 \mathrm{~mm}$, Neodent, 


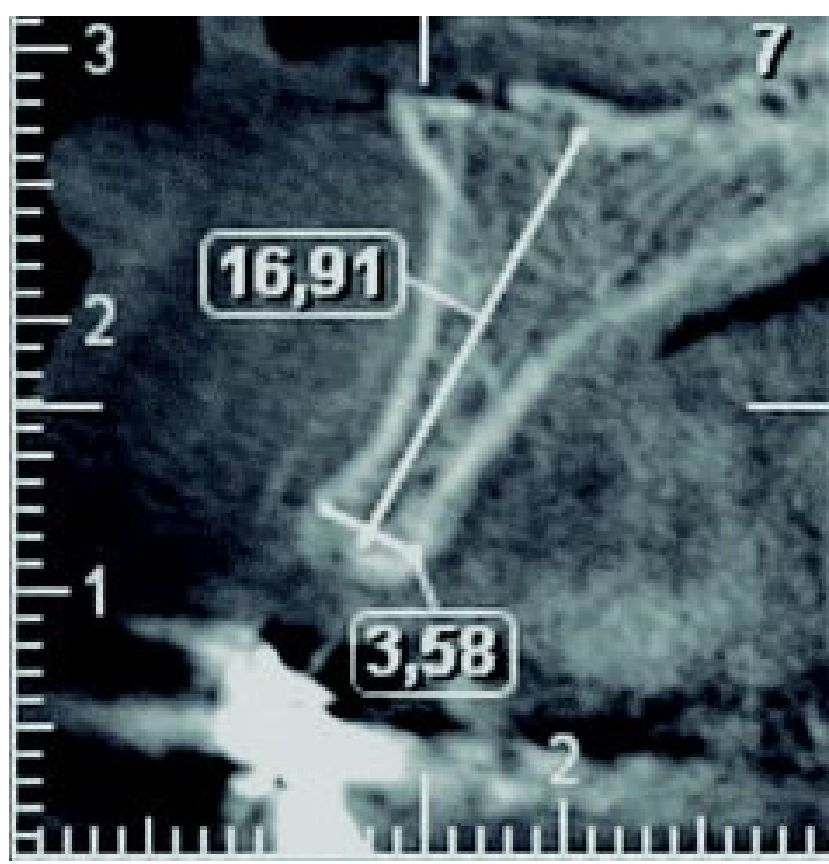

Fig. 3. Tomographic section of the region around element 11 , showing vestibular bone loss. However, the quantity of bone remaining is sufficient for the installation of a reduced diameter implant.

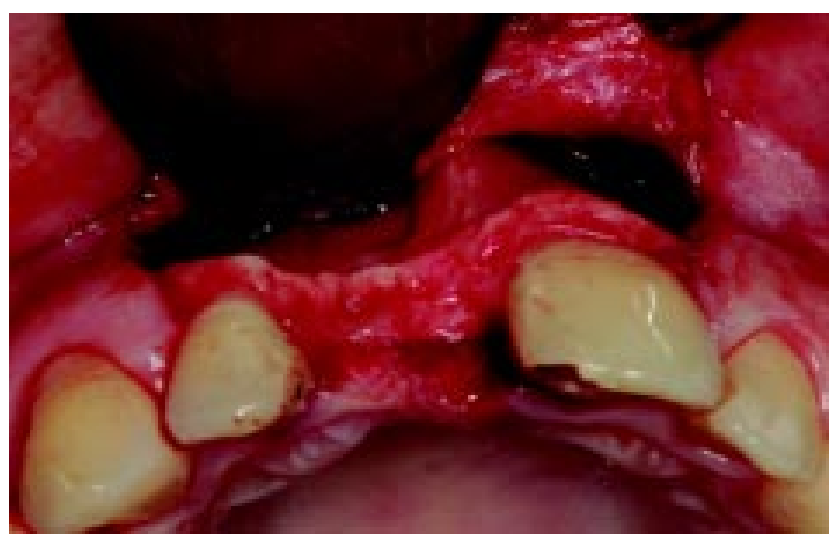

Fig. 4. Occlusal view after the incision and mucoperiosteal detachment. It is possible to see the existing bone defect, as well as the remaining bone where the implant will be installed.

Curitiba-Brazil), a slight fracture of the buccal bone plate was noted, although it was not significant enough to prevent the completion of the procedure. The torque achieved while placing the implant was $35 \mathrm{Ncm}$ (Fig. 5).

Subsequently, a bovine block bone graft was inserted into the region of the bone depression (Lumina-Bloco, Critéria, São CarlosBrazil). This graft was duly prepared, adapted

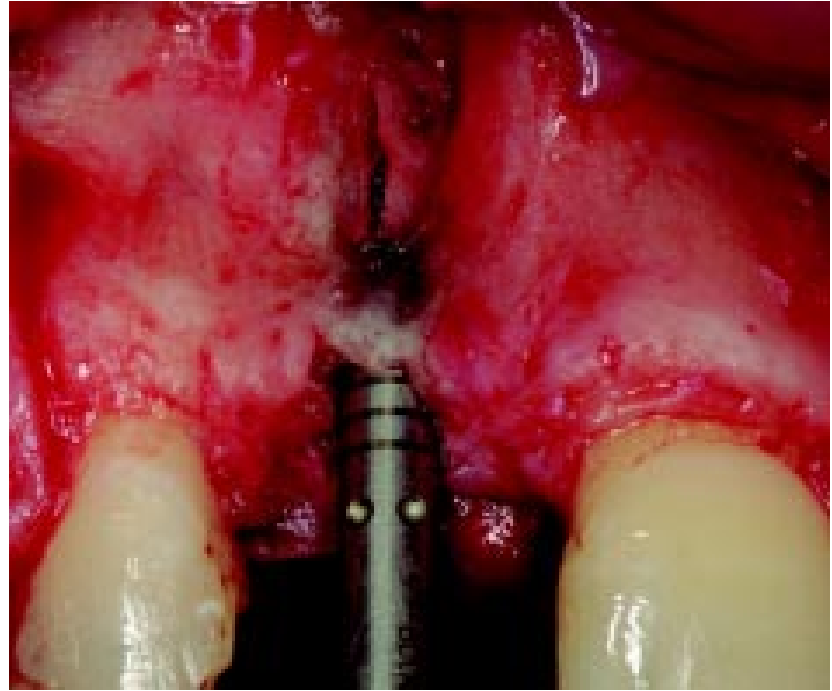

Fig. 5. Titamax Cone Morse 3.5x11 implant (Neodent, Curitiba-Brazil) installed. Note that there was a slight fracture of the buccal bone plate.

and fixed using a screw (Neodent, CuritibaBrazil) and the positional technique. The fixation of the screw was carried out in the space existing between the implant and the root of element 12 (Fig. 6).

The spaces existing between the adapted block and the native bone were filled with biomaterial in particulate form (Critéria, São Carlos-Brazil) to prevent the soft tissue from invading the surfaces. A membrane of absorbable collagen (Lumina-Coat Double Time,

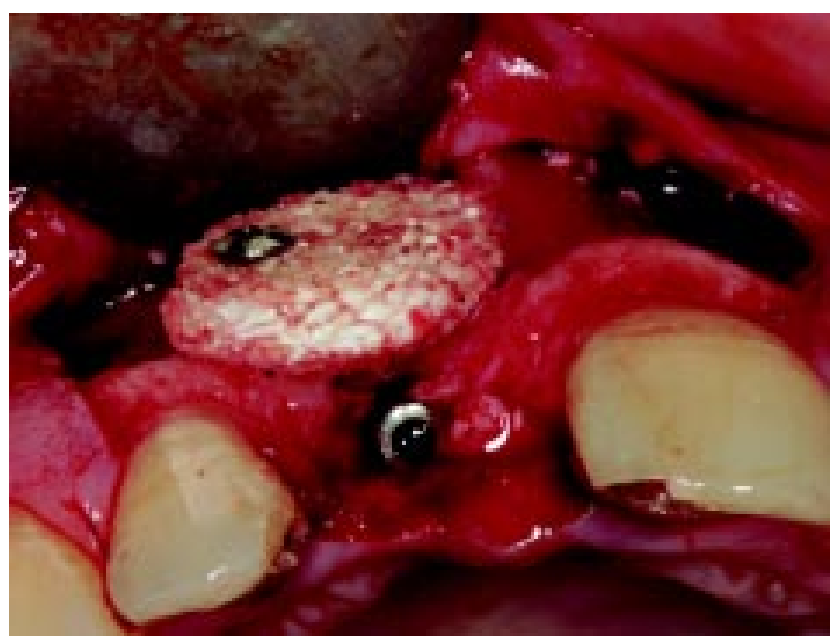

Fig. 6. Xenogeneic block bone graft (Critéria, São Carlos-Brazil), adapted and fixed in the region of the vestibular bone defect. The fixation screw was placed in the space between the implant and the root of element 12. 
Critéria, São Carlos-Brazil) was placed over the entire graft and the procedure was finished using suture (Fig. 7). The provisional prosthesis was adapted so that it would not put pressure on the reconstructed area.

Thirty days after the graft procedure had been completed, the patient was reassessed. An excellent gain in thickness was recorded in the area, as well as the complete correction of the pre-existing defect, thereby improving the esthetics of the region. Another significant factor was the appearance and health of the soft tissues involved (Fig. 8). The tomographic examination, which was carried out six months after the operation, showed an excellent gain in thickness on the element region 11 , correcting aesthetic defects presented by the patient (Fig. 9).

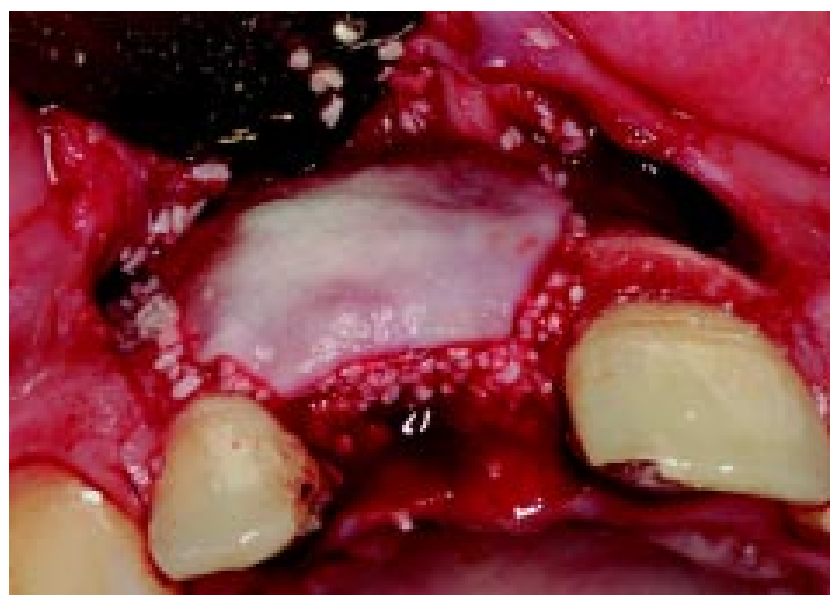

Fig. 7. Positioning of the lyophilized bone and the membrane of absorbable collagen. These materials were used to fill the eventual spaces between the surface of the graft and the native bone, while also preventing the soft tissue from invading the surfaces of the graft.

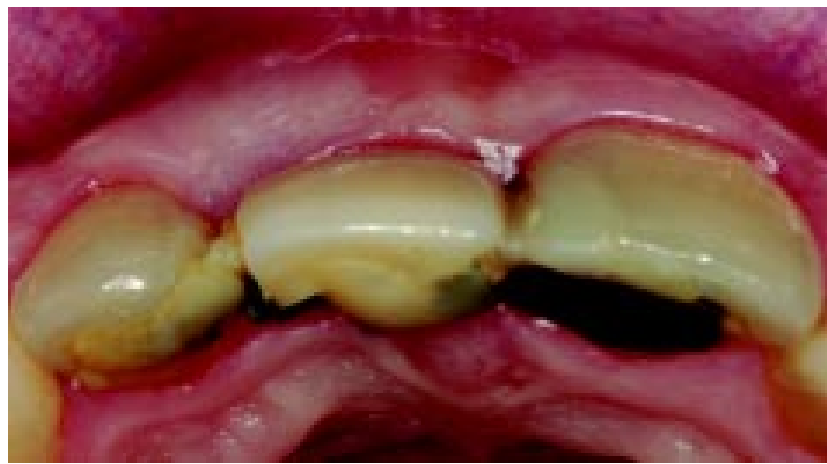

Fig. 8. Occlusal view 30 days post-surgery. Note the complete correction of the defect, as well as the healthy aspect of the soft tissue.

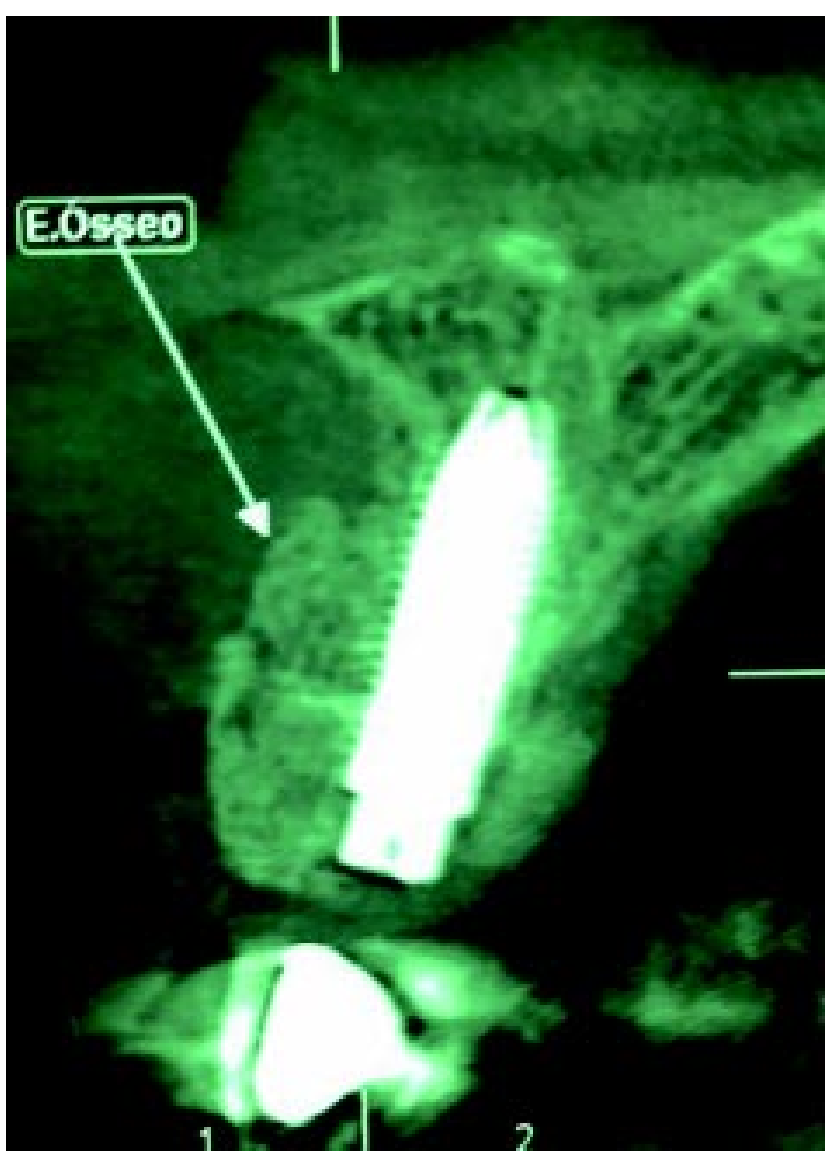

Fig. 9. Computerized tomography 180 days after the surgery, showing an excellent increase in thickness and the satisfactory positioning of the installed implants.

\section{DISCUSSION}

Currently, patients that request dental implants may wish to restore their masticatory function, comfort, esthetics and phonetics, regardless of the existence of bone atrophy, disease or an injury to the stomatognathic system (Olate et al., 2008; Nóia et al., 2012a, 2012b; Rickert et al., 2012). In this context, bone grafts on the alveolar ridge, particularly those of the autogenous variety, constitute a predictable, viable and long-lasting option for the treatment of these individuals (Clementini et al.,2011; Quiles et al., 2015).

In an attempt to overcome the difficulties involved in the use of autogenous bone as bone graft material (morbidity and risk of 
complications), several other types of material (biomaterial) are available on the market. The evolution and improvement of these biomaterials, particularly in particulate form, means that they can now be used safely in the maxillary sinus, dental alveoli and in the treatment of screws exposed by implants (Kühl et al., 2012, 2013; Rickert et al.; Mordenfeld et al., 2014; Schmitt et al., 2014).

Biomaterial is also available in block form, although this material is not trusted by most professionals. Many industries have stated that this material is capable of substituting autogenous grafts (Steigmann, 2008; Rothamel et al.; Li et al.; Xuan et al.). However, it is important to understand and consider that these materials are merely osteocoductors and no studies have as yet demonstrated their capacity. There are also doubts about whether xenogenous blocks can provide adequate osteointegration or maintain this osteointegration when faced with masticatory forces over a long period of time.

Based on the capacity of an organism's cells to invade adjacent tissues, perhaps a minimal gain (of up to $1.5 \mathrm{~mm}$ ) could be observed when using xenogenous blocks. However, this is just a hypothesis and requires more evidence in future studies. This would be similar to the small gain in the maxillary sinus, which can only be obtained by detaching the sinus membrane.

In this clinical case, the material was shown to be useful in terms of correcting an esthetic bone defect in the maxillary anterior region, provided there was enough bone left to install the dental implant. This is probably the real indication for the use of this material, which can even maintain the long-term stability of tissues.

Xenogenous blocks exhibit certain peculiarities that must be taken into consideration at the time of use. Firstly, this material exhibits little mechanical resistance and tends to crumble during its modeling and fixation. Therefore, extreme care must be taken by the surgeon in order to prevent the material from hydrating. Another significant factor is the difficulty associated with positioning the screw that holds the block in place, given that the ideal fixation site is occupied by the dental implant itself. In this clinical case, the fixation was performed by placing the screw between the implant and the root of element 12, taking extreme care not to damage the root during the procedure.

\section{CONCLUSIONS}

The xenogenous block bone graft used in this clinical case was confirmed as a viable option in the treatment of esthetic defects. Further studies are required to assess their stability and long-term tissue maintenance, as well as the possibility of associated bone neoformation.

ROCHA, P. B.; DA SILVA, C. T.; DE SANTANA-JÚNIOR, S. S.; CAMARGO, V. M.; NÓIA, C. F. \& DE SÁ, B. C. M. Consideraciones en el uso de Injerto en Bloque Xenógeno en Implantología: Reporte de Caso. Int. J. Med. Surg. Sci., 2(2):469-474, 2015.

RESUMEN: En Implantología, aumentos en el ancho del reborde alveolar son asociadas a menudo con hueso autógeno, el cual es considerado el patrón de oro. El objetivo de este estudio fue reportar el caso clínico de un paciente con ancho óseo anormal, causando un defecto estético severo, junto al uso de un bloque de xenoinjerto. Una mujer de 43 años de edad presentó un defecto óseo considerable en la región de diente 11 (ausente), aunque hubo suficiente hueso nativo para soportar la implantación. El tratamiento de la paciente consistió en la instalación del implante junto a un bloque óseo de origen bovino. El periodo postoperatorio se desarrolló sin complicaciones; los exámenes postoperatorios confirmaron la corrección del defecto estético prexistente y la recuperación del tejido blando involucrado. El estudio tomográfico posterior de 180 días confirmó el aumento óseo en ancho. El hueso bovino el bloque usado mostró la viabilidad en términos de la corrección estética del defecto cuando existe suficiente hueso autógeno para recuperar la implantación.

PALABRA CLAVE: Aumento de reborde alveolar; Trasplante óseo; Implante dental. 
ROCHA, P. B.; DA Silva, C. T.; DE SANTANA-JúnioR, S. S.; CAMARgo, V. M.; NóIA, C. F. \& DE SÁ, B. C. M. Considerations on the use of xenogenous bone blocks in implantology: A case report. Int. J. Med. Surg. Sci., 2(2):469-474, 2015.

\section{REFERENCES}

Clementini, M.; Morlupi, A.; Agrestin, L. \& Ottria L. Success rate of dental implants inserted in autologous bone graft regenerated areas: a systematic review. Oral Implantol. (Rome), 4(34):3-10, 2011.

Kühl, S.; Gotz, H. ; Brochhausen, C. ; Jakse, N. ; Filippi, A.; d'Hoedt, B. \& Kreisler, M. The influence of substitute materials on bone density after maxillary sinus augmentation: a microcomputed tomography study. Int. J. Oral Maxilofac. Implants, 27(6): 1541-6, 2012.

Kühl, S.; Brochhausen, C.; Gotz, H. ; Filippi, A.; Payer, M.; d'Hoedt, B. \& Kreisler, M. The influence of bone substitute materials on the bone volume after maxillary sinus augmentation: a microcomputerized tomography study. Clin. Oral Investig., 17(2):543-51, 2013.

Li, J.; Xuan, F.; Choi.; B. H. \& Jeong, S. M. Minimally Invasive Ridge Augmentation Using Xenogenous Bone Blocks in an Atrophied Posterior Mandible: A Clinical and Histological Study. Implant Dent., 22(3):112-6, 2013.

Mordenfeld, A.; Albrektsson, T. \& Hallman, M. A 10Year Clinical and Radiographic Study of Implants Placed after Maxillary Sinus Floor Augmentation with an 80:20 Mixture of Deproteinized Bovine Bone and Autogenous Bone. Clin. Implant Dent. Relat. Res., 16(3):435-46, 2014.

Nóia, C. F.; Ortega-Lopes, R.; Mazzonetto, R. \& Chaves Netto H. D. M. Segmental osteotomy with interpositional bone grafting in the posterior maxillary region. Int. J. Oral maxillofac. Surg., 41(12): 1563-5, 2012a.

Nóia, C. F.; Ortega-Lopes, R. ; Sato, F. R. L.; Olate, S. \& Mazzonetto, R. Estudio Radiográfico Prospectivo de la Reparación Ósea em Sínfisis Mandibular Posterior a la Remoción Ósea de Mentón. Int. J. Morphol., 30(1): 100-4, 2012b.

Olate, S.; Kluppel, L. E.; Chaves Netto, H. D. M.; Jaimes, M.; Albergaria-Barbosa, J.R.; \& Mazzonetto, R. Reposición maxilar y reconstrucción con cresta iliaca. Parte 1 . Indicaciones y técnica quirúrgica. Int. J. Odontoestomat., 2:43-52, 2008.

Quiles, J. C.; Bassi, A. P. F.; Garcia Jr, I. R.; França, M. T.; \& Carvalho, P. S. P. Survival rate of osseointegrated implants in atrophic maxillae grafted with calvarial bone: a retrospective study. Int. J. Oral Maxillofac. Surg. 44:239-4, 2015.

Rickert, D.; Slater, J. J.; Meijer, H. J.; Vissink, A. \& Raghoebar, G. M. Maxillary sinus lift with solely autogenous bone compared to a combination of autogenous bone and growth factors or (solely) bone substitutes. A systematic review. Int. J. Oral Maxillofac. Surg., 41(2):160-7, 2012.

Rothamel, D.; Schwarz, F.; Herten, M.; Nat, R.; Ferrari, D.; Mischkowski R. A.; Sager, M. \& Becker, J. Vertical Ridge augmentation using xenogenous bone blocks: A histomorphometric in dogs. Int. J. Oral Maxillofac. Implants, 24(2):243-50, 2009.

Schmitt, C. M.; Moest, T.; Lutz, R.; Neukam, F. W. \& Schlegel, K. A. Anorganic bovine bone (ABB) vs. autologous bone $(A B)$ plus $A B B$ in maxillary sinus grafting. A prospective non-randomized clinical and histomorphometrical trial. Clin. Oral Implants Res., 26(9): 1043-50, 2015.

Steigmann, M. A bovine-bone mineral block for the treatment of severe ridge deficiencies in the anterior region: A clinical case report. Int. J. Oral Maxillofac. Implants, 23(1):123-8, 2008.

Xuan, F.; Lee, C. U.; Son, J. S.; Fang, Y.; Jeong, S. M. \& Choi, B. H. Vertical Ridge Augmentation Using Xenogenous Bone Blocks: A Comparison Between the Flap and Tunneling Procedures. J. Oral Maxillofac. Surg., 72(9):1660-70, 2014.

Correspondence to:

Claudio Ferreira Nóia

University of Araras (UNIARARAS)

College Ciodonto

Dentistry Department.

Av. Dr. Maximiliano Baruto, 500

Jardim Universitário

Araras - São Paulo

BRAZIL

Zip-code: 13607-339

Phone: (55) (19) 3543-1400

Email: claudioferreira2004@yahoo.com.br claudionoia@uniararas.br

Received:20-04-2015

Accepted:22-06-2015 